International Journal of STEM Education for Sustainability, Vol.2, No.1, 2022, pp. 66-77

e-ISSN 2798-5091 DOI. 10.52889/ijses.v2i1.40

\title{
Learning Innovations: Students' Interest and Motivation on STEAM-PjBL
}

Submitted 26 November 2021 Revised 16 December 2021 Accepted 16 December 2021

\author{
Siti Suryaningsih ${ }^{1 *}$, Fakhira Ainun $\mathrm{Nisa}^{2}$, Buchori Muslim $^{3}$, Fauzan Aldiansyah ${ }^{4}$ \\ ${ }^{1,2,3}$ Department of Chemistry Education, Faculty of Tarbiya and Teaching Sciences, \\ Universitas Islam Negeri Syarif Hidayatullah Jakarta, Tangerang Selatan, Indonesia \\ ${ }^{4}$ Department of English Education, Faculty of Tarbiya and Teaching, \\ Universitas Islam Negeri Syarif Hidayatullah Jakarta, Tangerang Selatan, Indonesia \\ Corresponding Email: *siti.suryaningsih@uinjkt.ac.id
}

\begin{abstract}
The purpose of this study was to 1) determine the results of the prerequisite test of the research instrument consisting of tests of validity, reliability, and normality, 2) know students' responses to interest and motivation to learn using chemistry learning innovations. The method used is descriptive quantitative. A sample of 76 students was selected by purposive sampling at one of the senior high schools in Indonesia. Data was collected using a questionnaire instrument with ten items arranged based on a Likert scale based on student interest and motivation indicators on the acid-base titration concept. The instrument used was declared valid, and reliability was proven by a corrected item-total correlation of 10 items. Each of them has a value of more than 0.325 . A reliability value of 0.785 and a significance value of 0.2 indicates that the data is normally distributed. The Science, Technology, Engineering, Arts, and Mathematics-Project Based Learning (STEAM-PjBL) innovation received a good response from students in the form of a high percentage of interest and learning motivation. Students' interest in learning got an average score of 4.17 in the high category of $83.4 \%$. Likewise, learning motivation scored 4.22 in the high category of $84.4 \%$. In general, student responses gave positive responses or agreed to the application of STEAM$\mathrm{PjBL}$ in chemistry learning because it gave students high interest and motivation to learn. The results of this study can be used as innovations in the science learning process.
\end{abstract}

Keywords: Interest, Motivation, STEAM, Project Based Learning

\section{INTRODUCTION}

Some students still see chemistry learning as textual and theoretical learning (Park et al., 2016; Subagia, 2014). It is also considered problematic because the material is abstract, causing low interest and motivation of students in learning chemistry (Gurses et al., 2015). Learning has a dominant role in determining the quality of education. The quality of learning can be seen from the interest and motivation of students during the learning process (Taufiq et al., 2021). Chemistry teacher in the 21 st century has their challenges in implementing effective learning innovations and attracting student interest and motivation because some students are less interested in chemistry lessons which tend to be complicated. Therefore, chemistry learning innovation is very important to increase students' interest and motivation to learn.

Implementation of project-based learning based on STEAM (Science, Technology, Engineering, Art, Mathematics) is one of the learning innovations that can increase students' interest and motivation in learning (Suryaningsih et al., 2021). STEAM in education is 
defined as interdisciplinary learning that combines aspects of 'Art' into STEM (Dasuki et al., 2020; Hlukhaniuk et al., 2020), which has the aim of increasing student creativity (Bertrand \& Namukasa, 2020; Chung et al., 2020; Lee, 2020; Quigley et al., 2020). While Project-based learning can be used to develop science process skills so that students become more creative, active, and have the skills to create a product that has benefits and, of course, quality (Nasir et al., 2019). With STEAM-based and Project-Based Learning (PjBL), students get a fun learning experience by completing one or several projects that are very relevant to everyday life (Guo \& Tang, 2021; Nurulwati et al., 2021). Nuriani \& Muliawan (2020) stated that 95\% of students are interested in studying science if it is related to the surrounding environment or daily life.

A lot of STEAM research has been done. However, the innovation of STEAM-Projectbased learning in chemistry subjects utilizing social media Instagram is still minimal, so research needs to be done. In addition, researchers feel the need to know how much interest and motivation in learning students use STEAM-PjBL in chemistry subjects. This study aimed to determine the results of the prerequisite test of the research instrument consisting of tests of validity, reliability, and normality. Additionally, to find out students' responses to their interests and learning motivation by using chemistry learning innovations.

\section{METHOD}

This research was conducted using a quantitative descriptive method because it analyzed numerical data into a data description (Siyotoko \& Sodik, 2015). The subjects of this study were in class XI IPA at one of the high schools in Indonesia selected by purposive sampling. A sample of 76 students consists of 24 boys and 52 girls.

Data retrieval using a questionnaire instrument consisting of 10 items arranged based on student interest and motivation indicators in learning chemistry of acid-base titration concept. The questionnaire instrument using a Likert scale from a scale of 1 to 5 with the interpretation: 1 = Strongly Disagree; 2 = Disagree; 3 = Moderately Agree; 4 = Agree; $5=$ Strongly Agree.

Data analysis using the following formula:

$$
P=\frac{f}{N} \times 100 \%
$$

Descriptions:

$\mathrm{P}=$ Percentage number

$\mathrm{f}=$ Obtained raw score

$\mathrm{N}=$ Highest score in the questionnaire 
(Fatmawati, 2016).

Furthermore, the percentage values are categorized based on (Setiawan et al., 2021): 1.0 $50.0 \%$ (very low), $50.1-70.0 \%$ (low), $70.1-85.0 \%$ (high), and $85.1-100 \%$ (very high).

The implementation of chemistry learning innovation using the STEAM-PjBL approach on acid-base titration concept. The learning process of this study is determining the basic questions, preparing project plans, compiling schedules, monitoring, testing results, and evaluating experiences (Ministry of Education and Culture, 2013).

Table 1. Stages of STEAM-PjBL in Chemistry Learning on Acid-Base Concepts

\section{Introductory question}

What if there are no acid-base indicators in the laboratory?

Are there any other alternatives?

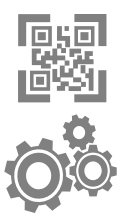

\section{Planning a project}

Deliver and discuss projects that students will carry out.

\section{Schedule}

Develop a timeline for project implementation (schedule preparation)

\section{Project monitoring}

The teacher oversees the project, students do research and get direct experience in identifying problems, looking for scientific research data results obtained from articles or journals. Students can describe

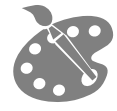
information about natural acid-base indicators into a scientific e-poster. The scientific e-poster is then uploaded to a digital/social media platform (Instagram).

\section{Testing project results}

Assessing student project results

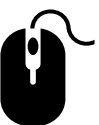

\section{Experience evaluation}

Evaluating and reflecting on projects based on student experience.

(Suryaningsih \& Nisa, 2021)

Innovation of acid-base titration chemistry learning with aspects of STEAM Figure 1.

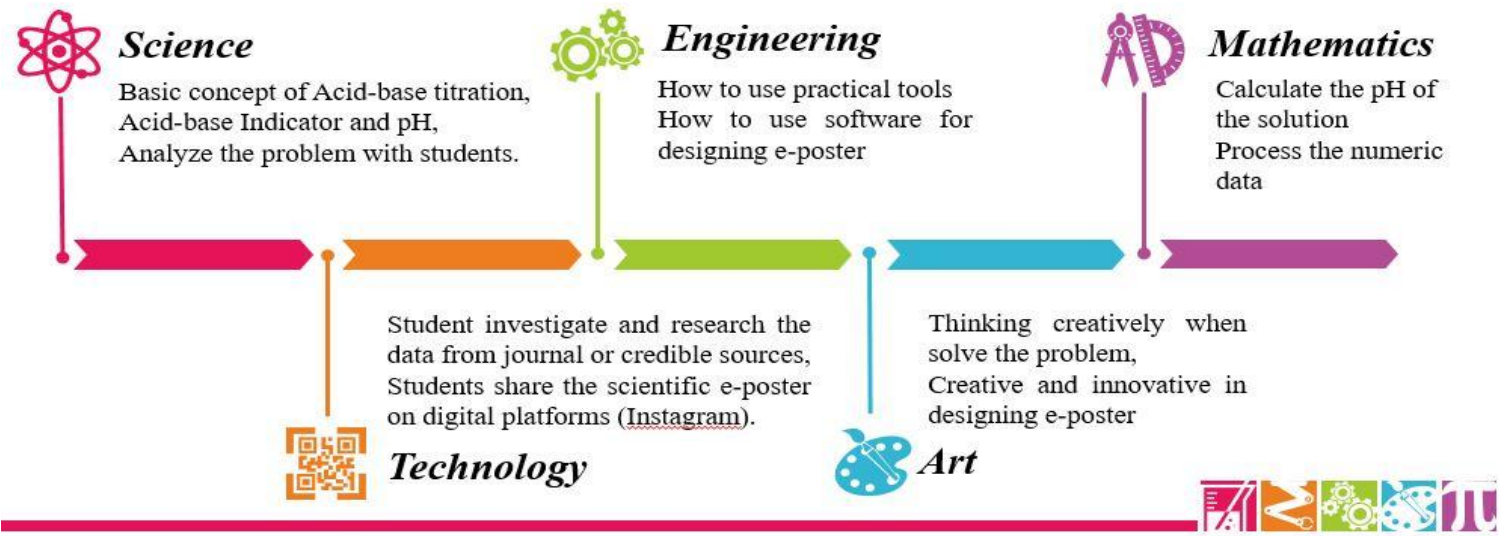

Figure 1. Integration of Acid-Base Titration Concepts with STEAM aspects (Suryaningsih \& Nisa, 2021). 
The innovation of acid-base titration chemistry learning with STEAM aspects is carried out to support students' skills in the 21 st century. The "Science" aspect of chemistry can train conceptual thinking skills. The "technology" aspect of learning can improve students' digital literacy and interact with digital society. Aspects of "Engineering" in learning chemistry can support students' skills related to the technique of using or operating a tool. The "Art" aspect in learning can improve students' creative and innovative thinking skills. The "mathematical" aspect of learning chemistry can train students to process numerical data, analytical and mathematical thinking skills (Suryaningsih \& Nisa, 2021). All of these aspects, if integrated into a lesson, will give the impression of being fun and not boring to increase students' interest and motivation in learning chemistry (Suryaningsih et al., 2021).

\section{RESULTS AND DISCUSSION}

\section{Instrument Prerequisite Test}

The results of the instrument prerequisite test include tests of validity, reliability, and normality. Validity test results using SPPS Table 2.

Table 2. Validity Tests Results

\begin{tabular}{lccccc}
\hline Number Item & Q1 & Q2 & Q3 & Q4 & Q5 \\
\hline Pearson & $.665^{* *}$ & $.671^{* *}$ & $.722^{* *}$ & $.646^{* *}$ & $.651^{* *}$ \\
Correlation & & & & & .000 \\
Sig. (2-tailed) & .000 & .000 & .000 & .000 \\
$\mathrm{~N}$ & 76 & 76 & 76 & 76 & 76 \\
\hline Number Item & $\mathrm{Q} 6$ & $\mathrm{Q} 7$ & $\mathrm{Q} 8$ & $\mathrm{Q} 9$ & $\mathrm{Q} 10$ \\
\hline Pearson & $.776^{* *}$ & $.759^{* *}$ & $.737^{* *}$ & $.816^{* *}$ & $.832^{* *}$ \\
Correlation & & & & & \\
Sig. (2-tailed) & .000 & .000 & .000 & .000 & .000 \\
$\mathrm{~N}$ & 76 & 76 & 76 & 76 & 76 \\
\hline
\end{tabular}

Based on Table 2, the validity of the ten questions in the form of positive statements obtained the results of the calculated r-value for all questions that were each greater than 0.325 , and the $\mathrm{r}$ table value for $\mathrm{n} 76$ at $5 \%$ significance was 0.325 . This shows that the items are declared valid. Instrument questions are valid if the $\mathrm{R}$ count is more than the $\mathrm{R}$ table (Rustam et al., 2018). The results of the reliability test of the questions are in Table 3.

Table 3. Reliability Statistics

\section{Cronbach's}

Alpha $\quad \mathrm{N}$ of Items

.785 10 
Based on Table 3, each questionnaire item is declared reliable according to the results of the Reliability test calculation, with Cronbach's Alpha value $>0.6$, which is 0.785 . This shows that the questionnaire has consistency if the measurement with the questionnaire is carried out repeatedly. According to (Rustam et al., 2018) if a measuring instrument is used repeatedly to get the same results, then the measuring instrument is declared consistent or reliable. The normality test was conducted to test whether the data distribution in the study sample was normally distributed or not. For normality test in this study using Kolmogorov-Smirnov test.

Table 4. Normality Test Results

\begin{tabular}{llc}
\hline One-Sample Kolmogorov-Smirnov Test & \\
\hline & & \multicolumn{2}{c}{$\begin{array}{l}\text { Unstandardized } \\
\text { Residual }\end{array}$} \\
\hline $\mathrm{N}$ & 76 \\
Normal Parameters ${ }^{\mathrm{a}, \mathrm{b}}$ & Mean & .0000000 \\
& Std. Deviation & 2.75848182 \\
Most Extreme Differences & Absolute & .087 \\
& Positive & .057 \\
\multirow{2}{*}{ Test Statistic } & Negative & -.087 \\
Asymp. Sig. (2-tailed) & & .087 \\
\hline
\end{tabular}

Note:

a. Test distribution is Normal.

b. Calculated from data.

c. Lilliefors Significance Correction.

The results of the normality test using the Kolmogorov-Smirnov test using the formulation of the hypothesis to test the normality of the data, namely:

H0: data is not normally distributed

H1: data is distributed normally.

The test criteria used are if the probability value (sig.) $>0.05$, then $\mathrm{H} 1$ is accepted (normally distributed data), H0 is rejected (Rustam et al., 2018). Based on the KolmogorovSmirnov normality test results in table 4, the Asymp value is known. Sig. (2-tailed) of 0.2 which is worth $>0.05$, so it can be concluded that the data obtained are normally distributed.

\section{Analysis of Students' Responses to STEAM-PjBL in Chemistry Learning Student's Interest}

The results of data analysis of student interest in learning chemistry of acid-base titration concepts using the STEAM-PjBL innovation Table 5. 
International Journal of STEM Education for Sustainability, Vol.2, No.1, 2022, pp. 66-77

e-ISSN 2798-5091 DOI. 10.52889/ijses.v2i1.40

Table 5. Student's Interest Percentage

\begin{tabular}{lcc}
\hline Indicator & $\%$ & Category \\
\hline Interest & 85.6 & Very High \\
Initiative & 79.4 & High \\
Feeling Happy & 81.0 & High \\
Creative Thinking & 83.4 & High \\
Curiosity & 87.6 & Very High \\
\hline Average & 83.4 & High \\
\hline
\end{tabular}

Based on Table 5, the curiosity indicator got the highest percentage, which was $87.6 \%$ in the very high category. Meanwhile, the initiative indicator obtained the lowest percentage, namely $79.4 \%$ in the high category. Overall, student interest obtained an average percentage of $83.4 \%$, including the high category. This shows that students have a high interest in learning chemistry based on STEAM-PjBL. Previous research stated that activities that interest students are given continuous attention, accompanied by pleasure, and a sense of satisfaction is obtained (Aprilia et al., 2020). Lesson content that is considered 'meaningful' and personally interesting is a topic that is important or related to students' daily lives (Herro et al., 2016; Palmer, 2009).

Students show a very high interest in STEAM-based learning and like design activities (Mohd Shahali et al., 2019). Students participate in direct learning activities through collaborative problem solving (Jesionkowska \& Wild, 2020). The interest of these students can trigger students' creative thinking skills in chemistry learning (Manik et al., 2020). Interest describes the tendency of students to be involved in a project (Abbot et al., 2017). Therefore, the innovation of learning chemistry using STEAM-PjBL makes students interested in learning chemistry, especially in the acid-base titration concept.

Table 6. Student's Learning Interest Response

\begin{tabular}{|c|c|c|c|c|c|c|c|}
\hline \multirow{2}{*}{ Indicator } & \multirow{2}{*}{$\begin{array}{c}\text { Statements } \\
\text { (Responded aspect) }\end{array}$} & \multicolumn{5}{|c|}{ Answer Options } & \multirow{2}{*}{$\dot{\mathrm{x}} \mathrm{SCORF}$} \\
\hline & & 1 & 2 & 3 & 4 & 5 & \\
\hline Interest & $\begin{array}{l}\text { Students are interested in } \\
\text { STEAM project-based chemistry } \\
\text { learning by utilizing social media } \\
\text { Instagram }\end{array}$ & 0 & 1 & 10 & 24 & 41 & 4.28 \\
\hline Initiative & $\begin{array}{l}\text { Students have the initiative to } \\
\text { innovate with existing } \\
\text { technology to find and create } \\
\text { something useful. }\end{array}$ & 0 & 1 & 13 & 34 & 28 & 3.97 \\
\hline $\begin{array}{l}\text { Feeling } \\
\text { Happy }\end{array}$ & $\begin{array}{l}\text { Students feel happy to be } \\
\text { creative in making informative } \\
\text { posters related to natural acid- } \\
\text { base indicators. }\end{array}$ & 0 & 2 & 14 & 38 & 22 & 4.05 \\
\hline Creative & Students have the creativity to & 0 & 1 & 22 & 31 & 22 & 4.17 \\
\hline
\end{tabular}


International Journal of STEM Education for Sustainability, Vol.2, No.1, 2022, pp. 66-77

e-ISSN 2798-5091 DOI. 10.52889/ijses.v2i1.40

\begin{tabular}{|c|c|c|c|c|c|c|c|}
\hline \multirow{2}{*}{ Indicator } & \multirow{2}{*}{$\begin{array}{c}\text { Statements } \\
\text { (Responded aspect) }\end{array}$} & \multicolumn{5}{|c|}{ Answer Options } & \multirow{2}{*}{$\dot{\mathrm{x}} \mathrm{SCORE}$} \\
\hline & & 1 & 2 & 3 & 4 & 5 & \\
\hline Thinking & $\begin{array}{l}\text { apply science (chemistry) and } \\
\text { technology skills to create } \\
\text { something useful }\end{array}$ & & & & & & \\
\hline Curiosity & $\begin{array}{l}\text { Students will seek further } \\
\text { information if they still do not } \\
\text { understand the chemical } \\
\text { material related to the project } \\
\text { they are working on. }\end{array}$ & 0 & 3 & 7 & 32 & 34 & 4.38 \\
\hline & Average & & & & & & 4.17 \\
\hline
\end{tabular}

Based on Table 6, the average value of the curiosity indicator got the highest score, which was 4.38. Meanwhile, the initiative indicator received the lowest score, which was 3.97. Overall, student interest obtained an average score of 4.17. This shows that students' responses generally give positive responses or agree to the application of STEAM-PjBL in chemistry learning because it gives students' interest in learning. Interest is defined as an emotional motivator that affects learning by stimulating deeper processing strategies (Talley \& Martinez Ortiz, 2017). Therefore, the innovation of learning chemistry using STEAM-PjBL makes students interested in learning chemistry, especially in the acid-base titration concept.

\section{Students' Motivation}

The results of data analysis on student motivation in learning chemistry of acid-base titration concepts using the STEAM-PjBL innovation Table 7.

Tabel 7. Students' Motivation Percentage

\begin{tabular}{lcc}
\hline Indicator & $\%$ & Category \\
\hline Quality of Learning & 84.2 & High \\
Support & 88.6 & Very high \\
Hope & 81.6 & High \\
Enthusiasm & 83.2 & High \\
Desire & 84.2 & High \\
\hline Average & 84.4 & High \\
\hline
\end{tabular}

Based on Table 7, the highest percentage obtained by the support indicator is $88.6 \%$ in the very high category. While the percentage of the hope indicator gets the lowest result, which is $81.6 \%$ in the high category. However, each indicator's percentages get an average of $84.4 \%$. So, all indicators reach the category of high motivation. According to research, this shows that students have high motivation to learn chemistry using the innovative STEAMPjBL approach (Suryaningsih et al., 2021). As the results of previous research, motivation is an impulse that causes him to act and maintain that action (Laforce et al., 2017). Fun projects 
can increase student motivation (Vinko et al., 2020). With high motivation, students have a huge opportunity to achieve high achievements (Aprilia et al., 2020). Therefore, the innovation of learning chemistry using STEAM-PjBL motivates students to increase their enthusiasm in understanding concepts in chemistry learning, especially the acid-base titration concept.

Table 8. Student's Respond to Learning Motivation

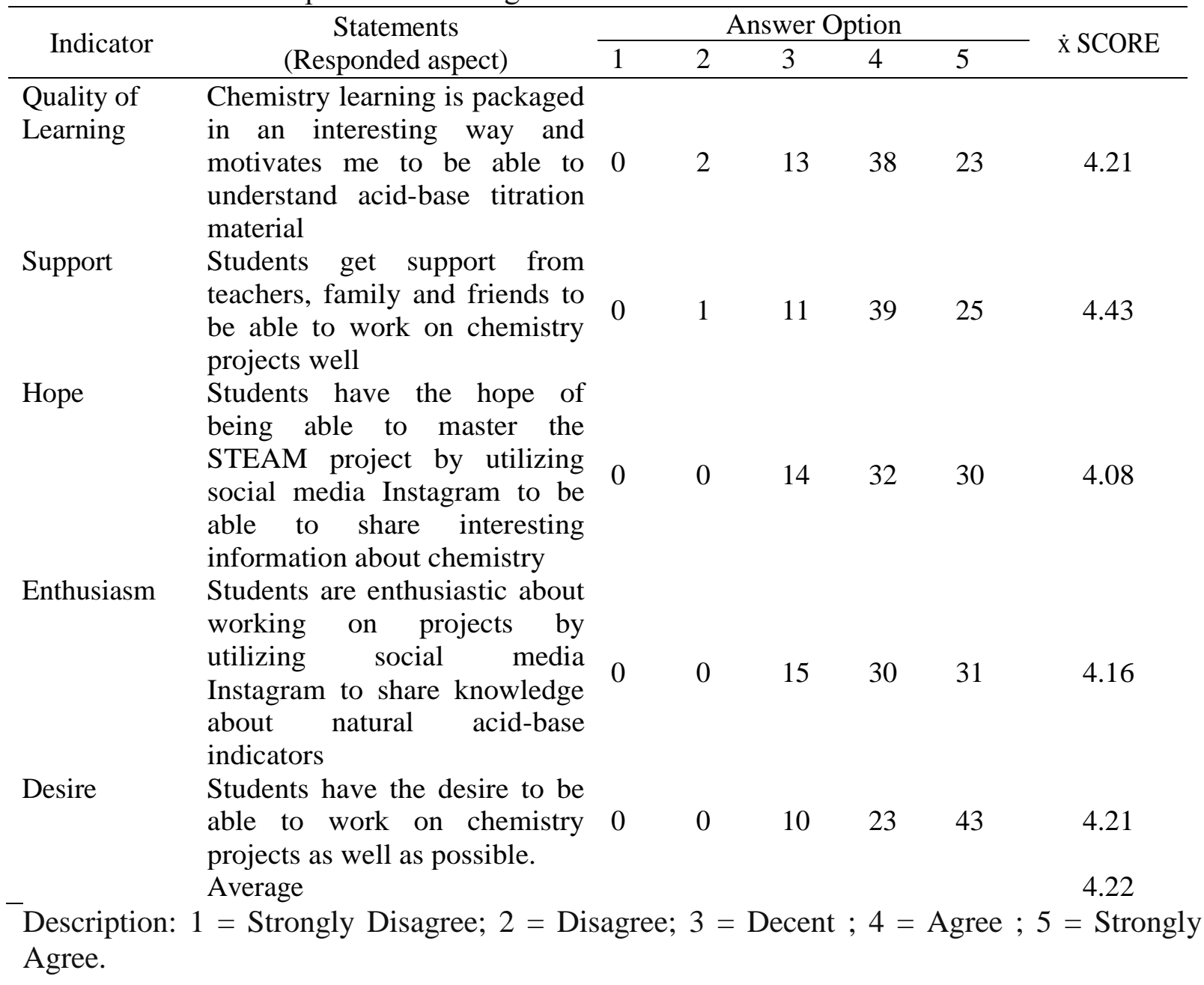

Based on Table 8, the average value of the support indicator gets the highest score, which is 4.43. While the hope indicator gets the lowest score, which is 4.08. Overall, students' motivation obtained an average score of 4.22. This shows that student responses generally give positive responses or agree to the application of STEAM-PjBL in chemistry learning because it provides student learning motivation. Students' motivation during the learning process will make it easier for them to understand the material's concept. The understanding of concepts obtained by students during the learning process shows the level of success of the learning itself (Alighiri \& Drastisianti, 2018) 
Motivation will be needed initially to make students want to participate in learning, and then it will be needed throughout the whole process until the learning is complete. Therefore, motivation is an essential prerequisite and prerequisite for learning (Palmer, 2009). STEAM provides new motivation in improving creativity, memory, motor coordination, and analytical skills. Students' high interest and motivation show that the STEAM-PjBL-based learning innovation is going well. This is in accordance with the objectives of STEAM learning, one of which is to design activities to attract and motivate students in interactive learning (Jung \& Hong, 2020). Therefore, the innovation of learning chemistry using STEAM-PjBL really encourages students to increase students' enthusiasm in understanding concepts in chemistry learning, especially the acid-base titration concept.

\section{CONCLUSION}

The results of the research instrument prerequisite test that the instrument used are valid, and the reliability is proven by the corrected item-total correlation of 10 items each having a value of more than 0.325 and a reliability value of 0.785 and a significance value of 0.2 , indicating that the data is normally distributed. The STEAM-PjBL in chemistry learning received a good response from students with a high percentage of interest and learning motivation. Students' interest in learning got an average score of 4.17 in the high category, $83.4 \%$. Likewise, his learning motivation scored 4.22 in the high category, namely $84.4 \%$. In general, student responses gave positive responses or agreed to the application of STEAM$\mathrm{PjBL}$ in chemistry learning because it provided high student interest and motivation.

\section{SUGGESTIONS}

This study only focused on analyzing student interest and motivation responses. It is better to do further research on chemistry learning innovations using STEAM-PjBL to improve students creativity, ICT literacy and critical thinking skills.

\section{REFERENCES}

Abbot, R., Mickail, T., Richards, T., \& Beers, S. (2017). Understanding Interest and SelfEfficacy in the Reading and Writing of Students with Persisting Specific Learning Disabilities during Middle Childhood and Early Adolescence. International Journal of Educational Methodology, 3(1), 41-64. https://doi.org/10.12973/ijem.3.1.41

Alighiri, D., \& Drastisianti, A. (2018). Pemahaman Konsep Siswa Materi Larutan Penyangga Dalam Pembelajaran Multiple Representasi. Pemahaman Konsep Siswa Materi Larutan Penyangga Dalam Pembelajaran Multiple Representasi, 12(2), 2192-2200.

Aprilia, F., Lustyantie, N., \& Rafli, Z. (2020). The effect of reading interest and achievement motivation on students' discourse analysis competence. Journal of Education and ELearning Research, 7(4), 368-372. https://doi.org/10.20448/journal.509.2020.74.368.372 
Bertrand, M. G., \& Namukasa, I. K. (2020). STEAM education: student learning and transferable skills. Journal of Research in Innovative Teaching \& Learning, 13(1). https://doi.org/10.1108/jrit-01-2020-0003

Chung, C. C., Huang, S. L., Cheng, Y. M., \& Lou, S. J. (2020). Using an iSTEAM projectbased learning model for technology senior high school students: Design, development, and evaluation. International Journal of Technology and Design Education. https://doi.org/10.1007/s10798-020-09643-5

Dasuki, A., Hawari, M., Iryani, A., \& Noor, M. (2020). Project Based Learning Pedagogical Design in STEAM Art Education. Asian Journal of University Education, 16(3), 102111.

Fatmawati, A. (2016). Pengembangan perangkat pembelajaran konsep pencemaran lingkungan menggunakan model pembelajaran berdasarkan masalah untuk SMA kelas X. EduSains, 4(2), 94-103. https://doi.org/https://doi.org/10.23971/eds.v4i2.512

Guo, C., \& Tang, Y. (2021). A Case Study of Thoroughly Integrated STEM PBL Course of Mechanics. Journal of Physics: Conference Series, 1-10. https://doi.org/10.1088/1742$6596 / 1732 / 1 / 012142$

Gurses, A., Dogar, C., \& Geyik, E. (2015). Teaching of the Concept of Enthalpy Using Problem Based Learning Approach. Procedia - Social and Behavioral Sciences, 197(February), 2390-2394. https://doi.org/10.1016/j.sbspro.2015.07.298

Herro, D., Quigley, C., Herro, D., \& Quigley, C. (2016). Innovating with STEAM in middle school classrooms: remixing education. Journal on the Horizon, 24(3), 190-204. https://doi.org/10.1108/OTH-03-2016-0008

Hlukhaniuk, V., Solovej, V., Tsvilyk, S., \& Shymkova, I. (2020). STEAM Education As a Benchmark For Innovative Training Of Future Teachers. Proceedings of the International Scientific Conference, 1, 211-221.

Jesionkowska, J., \& Wild, F. (2020). Education sciences Active Learning Augmented Reality for STEAM Education - A Case Study. Education Sciences, 10, 1-15. https://doi.org/doi.org/10.3390/educsci10080198

Jung, Y. K., \& Hong, H. (2020). A Theoretical Need for Applying Flipped Learning to STEAM Education.

Laforce, M., Noble, E., \& Blackwell, C. (2017). Problem-based learning (PBL) and student interest in STEM careers: The roles of motivation and ability beliefs. Education Sciences, 7(4). https://doi.org/10.3390/educsci7040092

Lee, S. S. (2020). Research on the developmental aspects of the steam education program development in Korea. Journal of Engineering Education Transformations, 34(2). https://doi.org/10.16920/jeet/2020/v34i2/155401

Manik, A. C., Suryaningsih, S., \& Muslim, B. (2020). Analisis Berpikir Kritis Kimia dalam Menyelesaikan Soal Two-Tier Berdasarkan Level Kemampuan Mahasiswa. Jambura 
International Journal of STEM Education for Sustainability, Vol.2, No.1, 2022, pp. 66-77

e-ISSN 2798-5091 DOI. 10.52889/ijses.v2i1.40

Journal of Educational Chemistry, 2(1), 28-39. https://doi.org/10.34312/jjec.v2i1.2999

Ministry of Education and Culture. (2013). Materi Pelatihan Guru: Implementasi Kurikulum 2013 SMA/MA, SMA/MAK Matematika. Ministry of Education and Culture

Mohd Shahali, E. H., Halim, L., Rasul, M. S., Osman, K., \& Mohamad Arsad, N. (2019). Students' interest towards STEM: a longitudinal study. Research in Science and Technological Education, 37(1), 71-89. https://doi.org/10.1080/02635143.2018.1489789

Nasir, M., Fakhrunnisa, R., \& Nastiti, L. R. (2019). The Implementation of Project-based Learning and Guided Inquiry to Improve Science Process Skills and Student Cognitive Learning Outcomes. International Journal of Environment \& Science Education, 14(5), 229-238.

Nuriani, \& Muliawan, W. (2020). Development of Science Learning with Project Based Learning on Science Process Skill: A Needs Analysis Study. International Conference of Technology and Education, 1-5. https://doi.org/10.1088/1742-6596/1539/1/012055

Nurulwati, Herliana, F., Elisa, \& Musdar. (2021). The Effectiveness of Project-Based Learning to Increase Science Process Skills in Static Fluids Topic. In A. Publishing (Ed.), AIP Conference Proceedings 2320 (Vol. 2320, Issue 020037, pp. 1-5). https://doi.org/https://doi.org/10.1063/5.0037628

Palmer, D. H. (2009). Student interest generated during an inquiry skills lesson. Journal of Research in Science Teaching, 46(2), 147-165. https://doi.org/10.1002/tea.20263

Park, H., Byun, S., \& Sim, J. (2016). Teachers ' Perceptions and Practices of STEAM Education in South Korea. Eurasia Journal of Mathematics, Science \& Technology Education, 12(7), 1739-1753. https://doi.org/10.12973/eurasia.2016.1531a

Quigley, C. F., Herro, D., Shekell, C., Cian, H., \& Jacques, L. (2020). Connected Learning in STEAM Classrooms: Opportunities for Engaging Youth in Science and Math Classrooms. International Journal of Science and Mathematics Education, 18(8). https://doi.org/10.1007/s10763-019-10034-z

Rustam, A., Sari, E. D. K., \& Yunita, L. (2018). Statistika dan Pengukuran Pendidikan. PT Ilham Sejahtera Persada.

Setiawan, R. R., Suwondo, \& Syafii, W. (2021). Implementation of Project Based Learning Student Worksheets to Improve Students' Science Process Skills on Environmental Pollution in High Schools. Journal of Educational Sciences, 5(1), 130-140. https://doi.org/http://dx.doi.org/10.31258/jes.5.1.p.130-140

Siyotoko, S., \& Sodik, A. (2015). Dasar Metodologi Penelitian (Ayup (ed.); Cetakan-1). Literasi Media Publishing.

Subagia, I. W. (2014). Paradigma Baru Pembelajaran Kimia SMA. Prosiding Seminar Nasional MIPA UNDIKSHA, 152-163. https://ejournal.undiksha.ac.id/index.php/semnasmipa/article/view/10479 
Suryaningsih, S., Muliharto, \& Nisa, F. A. (2021). Integrasi Science, Technology, Engineering, Art, Mathematics ( STEAM ) Project: Inovasi Pembelajaran Kimia terhadap Minat dan Motivasi Siswa. Prosiding Seminar Nasional FITK UIN Jakarta, 222-236. https://repository.uinjkt.ac.id/dspace/handle/123456789/56310

Suryaningsih, S., \& Nisa, F. A. (2021). Kontribusi STEAM Project Based Learning dalam Mengukur Keterampilan Proses Sains dan Berpikir Kreatif Siswa. Jurnal Pendidikan Indonesia, 2(6), 1097-1111. https://doi.org/https://doi.org/10.36418/japendi.v2i6.198

Talley, K. G., \& Martinez Ortiz, A. (2017). Women's interest development and motivations to persist as college students in STEM: a mixed methods analysis of views and voices from a Hispanic-Serving Institution. International Journal of STEM Education, 4(1). https://doi.org/10.1186/s40594-017-0059-2

Taufiq, A., Siantoro, G., \& Khamidi, A. (2021). Analisis Minat dan Motivasi Belajar Siswa Terhadap Pembelajaran Daring Pjok Selama Pandemi Coronavirus Disease ( Covid-19) di Man 1 Lamongan. Jurnal Education and Development, 9(1), 225-229.

Vinko, L., Delaney, S., \& Devetak, I. (2020). Teachers' opinions about the effect of chemistry demonstrations on students' interest and chemistry knowledge. Center for Educational Policy Studies Journal, 10(2), 9-25. https://doi.org/10.26529/cepsj.893 